\title{
Initial physic nut nutrition and potassium balance in the soil-plant system ${ }^{1}$
}

\author{
Mariângela B. Freiberger ${ }^{2}$, Iraê A. Guerrini ${ }^{3}$, Gustavo Castoldi ${ }^{4}$, Fábio Steiner ${ }^{5}$ \& Leonardo T. Büll ${ }^{6}$
}

${ }^{1}$ Parte da Dissertação de Mestrado da primeira autora

${ }^{2}$ FCA/UNESP. Botucatu, SP. E-mail: maia_bf@yahoo.com.br (Autor correspondente)

${ }^{3}$ FCA/UNESP. Botucatu, SP. E-mail: iguerrini@fca.unesp.br

${ }^{4}$ FCA/UNESP. Botucatu, SP. E-mail: castoldi@fca.unesp.br

${ }^{5}$ FIO. Ourinhos, SP. E-mail: fsteiner_agro@yahoo.com.br

${ }^{6}$ FCA/UNESP. Botucatu, SP. E-mail: bull@fca.unesp.br

\section{Key words:}

Jatropha curcas

dynamic of nutrient uptake

non-exchangeable $\mathrm{K}$

\begin{abstract}
A B S T R A C T
The objectives of this study were to evaluate the mineral nutrition and the response of physic nut to potassium fertilization as well as to assess whether the species can absorb $\mathrm{K}$ from the non-exchangeable soil fraction. The study was conducted in a greenhouse, in randomized blocks, and with four repetitions. Physic nut plants were cultivated in plastic recipients filled with $50 \mathrm{dm}^{3}$ of a Dark Red Latosol fertilized with rates of 0, 40, 80, 120 and $160 \mathrm{mg} \mathrm{K} \mathrm{dm}^{-3}$ of soil. One hundred and fifty days after planting, the height, stem diameter and leaf area of the plants were measured, and the dry mass, concentration in leaf and total accumulation of macro and micronutrients were determined, as well as the soil contents of exchangeable and non-exchangeable $\mathrm{K}$. The $\mathrm{K}$ balance in the soil-plant system was also calculated. The increase of potassium fertilization resulted in a greater uptake of $\mathrm{K}$, $\mathrm{Ca}$ and $\mathrm{Mn}$ but did not alter the total dry mass production of physic nut. The species can release and absorb $\mathrm{K}$ from the non-exchangeable soil fraction.
\end{abstract}

Palavras-chave: Jatropha curcas dinâmica de absorção K não-trocável

\section{Nutrição inicial do pinhão-manso e balanço de potássio no sistema solo-planta}

\begin{abstract}
R E S U M O
Objetivou-se, neste trabalho, avaliar a nutrição mineral e a resposta do pinhão-manso à adubação potássica, bem como se a espécie pode absorver K da fração não-trocável do solo. O estudo foi conduzido em estufa plástica, em blocos casualizados com quatro repetições. Plantas de pinhão-manso foram cultivadas em vasos plásticos preenchidos com $50 \mathrm{dm}^{3}$ de um Latossolo Vermelho Escuro testando-se as doses de 0, 40, 80, 120 e $160 \mathrm{mg} \mathrm{K} \mathrm{dm}^{-3} \mathrm{do} \mathrm{solo}_{\text {; após }}$ 150 dias do plantio foram mensurados altura, diâmetro de colo e área foliar das plantas e se determinou massa seca, teores foliares e acúmulo total de macro e micronutrientes, além dos teores de K trocável e K não-trocável do solo. O balanço do K no sistema solo-planta também foi calculado. O aumento da adubação potássica resulta em maior absorção de K, Ca e Mn mas não altera a produção de massa seca total do pinhão-manso. A espécie é capaz de disponibilizar e absorver $\mathrm{K}$ da fração não-trocável do solo.
\end{abstract}

\section{INTRODUCTION}

Physic nut (Jatropha curcas L.) is a native oleaginous species of South America which has seeds with an oil content of approximately $37.5 \%$ and desirable characteristics for fuel purposes (Arruda et al., 2004). The species is perennial, monoecious and belongs to the family Euphorbiaceae (Nithiyanantham et al., 2013), as does the castor bean and cassava; however, physic nut is in plant breeding phase in Brazil, which has garnered interest from various research areas (Bhering et al., 2012).

Regarding the fertilization and mineral nutrition of physic nut several studies have defined the best cultivation conditions, which describe the quantity, time and application method of fertilizers as well as the leaf diagnosis and the appropriate nutrient concentrations.
The requirement for potassium $(\mathrm{K})$ is known to be greater in the beginning of the reproductive phase of the plant (Laviola \& Dias, 2008), possibly because this nutrient acts in the transport of photoassimilates and participates in fruit formation (Marschner, 1995). Fully opened leaves at positions 2 and 3 from the apex are the most appropriate samples for its diagnosis (Lima et al., 2011b).

In a study with a nutrient solution, the omission of $\mathrm{K}$ reduced the production of dry matter by $85 \%$ in 120 -day-old physic nut plants (Silva et al., 2009), which underscores the importance of $\mathrm{K}$ for this species. When cultivated in the field, however, potassium fertilization did not affect growth and yield in the first and second years of physic nut growth (Oliveira et al., 2012).

The little or lack of response of this species to $\mathrm{K}$ fertilization, even in soils with low exchangeable $\mathrm{K}$ contents, is likely 
attributable to the contribution of the non-exchangeable $\mathrm{K}$ fraction in the soil that supplies the plant (Kamiski et al., 2007).

The $\mathrm{K}$ soil stock comprises the $\mathrm{K}$ in solution, exchangeable $\mathrm{K}$ (weakly retained in the CEC of the soil), non-exchangeable $\mathrm{K}$ (fraction of K "fixed" in the mineral structure) and structural $\mathrm{K}$ (resides in the interlayers of clay minerals and is slowly released by weathering). These forms maintain a specific equilibrium with the soil solution and define the $\mathrm{K}$ availability to the plants (Ernani et al., 2007). Under specific conditions, the exhaustion of $\mathrm{K}$ at the root surface produces a concentration gradient that causes the release of non-exchangeable $\mathrm{K}$ (Hinsinger et al., 1993), which can then be uptaken by the plants.

Some plants exhibit specific abilities, such as exuding organic acids (Wang et al., 2011) and accumulating cations in the root rhizosphere (Scherer, 1993), which can allow them to release $\mathrm{K}$ in varying magnitudes and absorb it from the non-exchangeable soil fraction (Rengel \& Damon, 2008). These observations can affect the crop management and must be considered in the fertilization program. Given the above, the objective of this study was to evaluate the mineral nutrition and the response of physic nut to $\mathrm{K}$ fertilization as well as to assess whether the species can release and absorb $\mathrm{K}$ from the non-exchangeable soil fraction.

\section{Material AND Methods}

The experiment was conducted under a greenhouse in the Department of Natural Resources/Soil Sciences of the College of Agronomic Sciences of the São Paulo State University Júlio de Mesquita Filho (FCA/UNESP), in Botucatu, SP, Brazil. During the experimental period, which lasted from October 2010 to February 2011, the maximum and minimum experimental temperatures were 41 and $21^{\circ} \mathrm{C}$, respectively. Five doses of K were evaluated: $0,40,80,120$ and $160 \mathrm{mg} \mathrm{dm}^{-3}$. The statistical delineation was performed in randomized blocks with four replicates. Each experimental unit was composed of a plastic recipient filled with $50 \mathrm{dm}^{3}$ of Dark Red Latosol of sandy texture (Carvalho et al., 1983) and contained a physic nut seedling. The chemical and physical analysis of the soil was performed (Table 1). The contents of exchangeable K (Raij et al., 2001) and non-exchangeable $\mathrm{K}$ (Knudsen et al., 1986) were also determined, which were 7.8 and $42.2 \mathrm{mg} \mathrm{dm}^{-3}$, respectively.

The base saturation was corrected to $60 \%$ by incorporating $2.3 \mathrm{~g}$ of soil of dolomitic limestone $\mathrm{dm}^{-3}$. The potassium, as potassium chloride, was incorporated in the soil 40 days after incubating the soil with limestone $(29 \% \mathrm{CaO}, 18 \% \mathrm{MgO}$ and 96\% PRNT), and the treatments also received fertilization with triple superphosphate (150 $\mathrm{mg} \mathrm{P} \mathrm{dm}^{-3}$ soil), urea $\left(80 \mathrm{mg} \mathrm{N} \mathrm{dm}^{-3}\right.$ soil) and micronutrients ( $0.012 \mathrm{~g}$ of manganese sulfate, $0.019 \mathrm{~g}$ of zinc sulfate and $0.005 \mathrm{~g}$ of boric acid $\mathrm{dm}^{-3}$ of soil).

Physic nut seedlings were produced in the Seedling Nursery of the FCA from seeds of the best genotypes of the EMBRAPA Semi-Arid (Brazilian Agency for Agricultural Research). The seedlings were developed in $116 \mathrm{~cm}^{3}$ tubes filled with the Carolina commercial substrate and suspended by fixed supports on the working benches of the germination in greenhouse for 45 days.

For planting, the seedlings were selected as a function of the development pattern; they exhibited an average height of $15 \mathrm{~cm}$, an average stem diameter of $0.8 \mathrm{~cm}$, one opened leaf and one newly developing leaf. The soil water content was monitored daily by weighing the vases and restoring the amount of water required to maintain the soil moisture close to $70 \%$ of the field capacity, as described by Ramos Júnior et al. (2013).

One hundred and fifty days after planting, the following parameters were measured: the stem diameter at $1 \mathrm{~cm}$ from the surface of the soil (using a digital caliper) and the height corresponding to the surface of the soil to the apical bud (using a graduated ruler).

The leaves were detached from the plants to determine the leaf area using Model LICOR LI-3000. Each plant was divided into the leaves, stem, petiole and root, which were packed in paper bags and kept in an oven at $60{ }^{\circ} \mathrm{C}$ with air circulation until a constant mass.

The dry plant matter was weighed, crushed in a Willey type mill and sampled to quantify the total concentrations of $\mathrm{N}, \mathrm{P}$, K, Ca, Mg, S, B, Cu, Fe, Mn and Zn (Malavolta et al., 1997). The total nutrient accumulation in the plant was determined by multiplying the total dry mass ( $\mathrm{g}$ ) by the total concentration of each nutrient and dividing by 1,000 to obtain the result in $\mathrm{g}$ and $\mathrm{mg}$, for macro and micronutrients, respectively.

The total quantity of each nutrient absorbed by the plant was obtained by summing the accumulated quantities in each part of the plant. With an open-probe type auger, three soil samples were also collected from each recipient. The soil was dried and after sieving in a $2 \mathrm{~mm}$ mesh to analyse the contents of exchangeable K (Raij et al., 2001) and non-exchangeable K (Knudsen et al., 1986).

The $\mathrm{K}$ balance in the soil-plant system was calculated based on the quantity of $\mathrm{K}$ provided via fertilization (in $\mathrm{g}$ ), the quantity of $\mathrm{K}$ absorbed by the plant (g), and the $\Delta \mathrm{K}$ in the soil - which represents the difference between the total quantity of exchangeable $\mathrm{K}$ in the soil before and after the cultivation of the plants, which was $0.39 \mathrm{~g}$ - calculated as suggested by Castilhos et al. (2002):

Table 1. Chemical and physical analysis of the soil

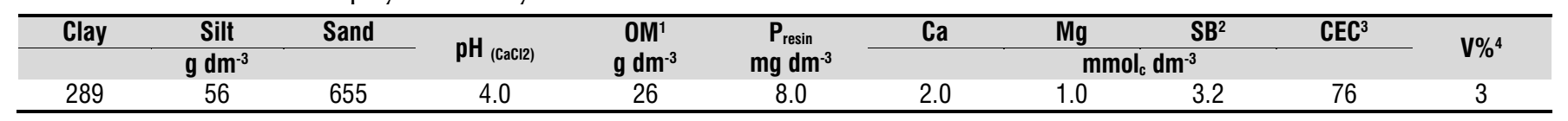

${ }^{1}$ Organic matter

${ }^{2}$ Sum of bases

${ }^{3}$ Cation exchange capacity;

${ }^{4}$ Base saturation 
$\Delta \mathrm{K}$ in soil $(\mathrm{g})=\mathrm{K}$ available at the end of the experiment - $\mathrm{K}$ initially available

For the calculation of $\Delta K$, the contents of exchangeable $K$ in the soil (in $\mathrm{mg} \mathrm{dm}^{-3}$ ) and the volume of soil used in each recipient $\left(50 \mathrm{dm}^{-3}\right)$ were considered. As the water supply was controlled, losses by leaching were disregarded. The K balance in the soil-plant system was calculated by subtracting the value of $\Delta \mathrm{K}$ in the soil from the difference between the $\mathrm{K}$ provided by fertilization and the total $\mathrm{K}$ uptaken by the plant, according to the following equation:

$\mathrm{K}$ balance in the soil-plant system $(\mathrm{g})=(\mathrm{K}$ fertilization -

- $\mathrm{K}$ uptake by plants $)-\Delta \mathrm{K}$ in soil

Negative values of the $\mathrm{K}$ balance in the soil-plant system represent the quantity of $\mathrm{K}$ released from the non-exchangeable fraction, and positive values represent the quantity of $\mathrm{K}$ added to the non-exchangeable and/or structural fractions.

To compare the effect of potassium fertilization on the $\mathrm{K}$ balance in the soil-plant system, the statistical test used was the comparison of means, using the confidence interval for the mean of $95 \%(p=0.05)$ (Payton et al., 2000). The other results were subjected to a variance analysis and $\mathrm{F}$ test. When a significant effect was verified, the data were analyzed by regression and adjusted to polynomial (linear or quadratic) or exponential equations of the type "Rise to Max", as a function of the regression parameters significance, the value of $\mathrm{F}$ and the adjusted coefficient of determination $\left(\mathrm{R}^{2}\right)$. When using the exponential equation, it is assumed that the appropriate rate (from which an increase in the value of y does not justify the increase in the rate) displays a value of "y" equal to $90 \%$ of the absolute value of the amplitude between " $y_{0}$ " and " $y_{\max }$ ". The statistical program SigmaPlot 10.0 was used to perform the statistical analysis and generate graphs.

\section{Results AND Discussion}

The potassium fertilization did not alter the concentrations of $\mathrm{P}, \mathrm{Ca}, \mathrm{S}, \mathrm{B}$ or $\mathrm{Cu}$, in leaf which displayed mean values of 2.04, $16.4,1.75 \mathrm{~g} \mathrm{~kg}^{-1}, 67.9$ and $5.85 \mathrm{mg} \mathrm{kg}^{-1}$, respectively (Table 2). The Mn concentration was adjusted to an exponential model, and its increase was extremely low, starting at a concentration of $127.7 \mathrm{mg} \mathrm{kg}^{-1}$ for a $\mathrm{K}$ rate of $50 \mathrm{mg} \mathrm{dm}^{-3}$ (Table 2). The $\mathrm{Mg}$ concentration in the leaves decreased with increasing $\mathrm{K}$ rates (Table 2), possibly as a function of the antagonistic effect between $\mathrm{K}$ and $\mathrm{Mg}$ (Meurer, 2006) that attenuates Mg absorption when the $\mathrm{K}$ concentration in the soil solution increases (Fonseca \& Meurer, 1997).

The foliar $\mathrm{N}$ concentration decreased with increasing potassium fertilization (Table 2). Nitrogen most notably interacts with $\mathrm{K}$, so the stimulus to growth produced by the addition of one of these nutrients can lead to a deficiency of the other via dilution (Cantarella, 2007). In fact, this effect was observed in the present study, once increasing $\mathrm{K}$ concentrations
Table 2. Regression equations referring to the concentration of $\mathrm{N}, \mathrm{P}, \mathrm{K}, \mathrm{Ca}, \mathrm{Mg}, \mathrm{S}\left(\mathrm{g} \mathrm{kg}^{-1}\right)$ and $\mathrm{B}, \mathrm{Cu}$, $\mathrm{Fe}, \mathrm{Mn}$ and $\mathrm{Zn}\left(\mathrm{mg} \mathrm{kg}^{-1}\right)$ in physic nut leaves as affected by $\mathrm{K}$ rates, 150 after transplant

\begin{tabular}{clc}
\hline Nutrient & \multicolumn{1}{c}{ Equation } & $\mathbf{R}^{2}$ and significance \\
$\mathrm{N}$ & $\mathrm{y}=33.61-0.0126 \mathrm{x}$ & $0.27^{* *}$ \\
$\mathrm{P}$ & $\mathrm{y}=2.04$ & $\mathrm{~ns}$ \\
$\mathrm{~K}$ & $\mathrm{y}=5,96+0,0463 \mathrm{x}$ & $0.88^{* *}$ \\
$\mathrm{Ca}$ & $\mathrm{y}=16.4$ & $\mathrm{~ns}$ \\
$\mathrm{Mg}$ & $\mathrm{y}=28.60-0.0493 \mathrm{x}$ & $0.64^{\star *}$ \\
$\mathrm{~S}$ & $\mathrm{y}=1.75$ & $\mathrm{~ns}$ \\
$\mathrm{~B}$ & $\mathrm{y}=67.95$ & $\mathrm{~ns}$ \\
$\mathrm{Cu}$ & $\mathrm{y}=5.85$ & $\mathrm{~ns}$ \\
$\mathrm{Fe}$ & $\mathrm{y}=109.05+0.1381 \mathrm{x}$ & $0.32^{\star *}$ \\
$\mathrm{Mn}$ & $\mathrm{y}=84.24+48.33\left(1-\mathrm{e}^{-0.0462 x}\right)$ & $0.74^{* *}$ \\
$\mathrm{Zn}$ & $\mathrm{y}=17.55+0.0137 \mathrm{x}$ & $0.19^{*}$ \\
\hline${ }^{*}$ significant at $0.01 ;{ }^{*}$ significant at $0.05 ; \mathrm{ns}-$ not significant by $\mathrm{F}$ test
\end{tabular}

lead to a linear increase of the dry matter (DM) of the leaves ( $y$ $=30.40+0.0674 \mathrm{x}, \mathrm{R}^{2}=0.19$, significant at 0.05$)$ and a decrease in the foliar $\mathrm{N}$ concentration (Table 2).

Linear increases in concentrations in the leaves were observed for $\mathrm{Fe}$ (maximum of $131.1 \mathrm{mg} \mathrm{kg}^{-1}$ ), $\mathrm{Zn}$ (maximum of $19.7 \mathrm{mg} \mathrm{kg}^{-1}$ ) and $\mathrm{K}$ (varied from 6.0 to $13.4 \mathrm{~g} \mathrm{~kg}^{-1}$ ) with increased $\mathrm{K}$ fertilization (Table 2 ). These values, particularly the foliar $\mathrm{K}$ concentration obtained with the rate of $160 \mathrm{mg} \mathrm{dm}^{-3}$ (13.7 $\mathrm{g} \mathrm{kg}^{-1}$ ), approach those observed by Laviola \& Dias (2008) in completely opened physic nut leaves and in the fructification phase. Lima et al. (2011a) studied the redistribution of macronutrients in physic nut leaves with distinct phenological stages and verified a $\mathrm{K}$ concentration of $37 \mathrm{~g} \mathrm{~kg}^{-1}$ in the growing leaves, $22 \mathrm{~g} \mathrm{~kg}^{-1}$ in the mature leaves and $13 \mathrm{~g} \mathrm{~kg}^{-1}$ in the leaf litter (recently fallen leaves).

The distinct foliar nutrient concentrations found in the literature for the species are due, mainly, to the fact that a standard which leaf (position and plant age) of physic nut should be collected remains lacking. In the present study, the foliar nutrient concentrations represent the average of all leaves of a plant in initial development; thus, any comparison with other results could be imprecise. In this scope, Lima et al. (2011a) confirmed that the leaves from positions 2 and 3 from the apex (considering only the completely expanded leaves) seem to be the most appropriate for analyzing the N, P, K, S, Cu, Fe, $\mathrm{Mn}$ and $\mathrm{Zn}$ concentrations. However, the appropriate mineral concentrations in the leaves for the species remain undefined, which also limits further comparisons and/or discussions.

Although an increase of foliar $\mathrm{K}$ concentration was observed (Table 2), this did not result in increases in height (average value of $92.1 \mathrm{~cm}$ ), stem diameter (average value of $3.2 \mathrm{~cm}$ ), DM of the petioles+stem (average value of $79.2 \mathrm{~g}$ plant $^{-1}$ ), root DM (average value of 25.2 g plant $^{-1}$ ) or total DM of physic nut (average value of $140.3 \mathrm{~g} \mathrm{plant}^{-1}$ ). This could be attributed to the fact that physic nut possibly absorbed more $\mathrm{K}$ than necessary, commonly known as "luxury consumption" (Meurer, 2006), which is characterized by an increase in mineral concentrations in the tissues without an induction of a response in growth (Pavinato et al., 2009). However, it is important to emphasize that the $\mathrm{K}$ stored into the leaves 
possibly would be used later, once it is very important for the fructification phase (Meurer, 2006; Laviola \& Dias, 2008).

Laviola \& Dias (2008) confirmed that in the production phase the $\mathrm{K}$ requirement by physic nut increases. This happens because the $\mathrm{K}$ works at the transportation of phloem photoassimilates, being an important nutrient for the fruit formation (Marschner, 1995). This same result also raises the hypothesis that physic nut, in its initial stages of development, does not require a large amount of K. Oliveira et al. (2012) also noted that potassium fertilization did not affect the growth and yield in the first and second year of physic nut cultivation in the field.

Potassium fertilization promoted a linear increase in the leaf area $\left(y=5449.41+18.48 \mathrm{x}, \mathrm{R}^{2}=0.29\right.$, significant at 0.01$)$ and $\mathrm{DM}$ of the leaves, the maximum values, obtained with a maximum $\mathrm{K}$ rate $\left(160 \mathrm{mg} \mathrm{dm}^{-3}\right)$, were $8,406.2 \mathrm{~cm}^{2}$ and $41.2 \mathrm{~g}$, respectively. Prado et al. (2004) also noted that $\mathrm{K}$ (rates up to $220 \mathrm{mg} \mathrm{dm}^{-3}$ ) is important for the increase in the leaf area in passion fruit (Passiflora edulis) seedlings. These responses occurred mainly because, among the innumerable functions of $\mathrm{K}$ in the plant, the activation of enzymes that participate in photosynthesis and respiration, processes that participate in the metabolism of the leaf, are emphasized (Ernani et al., 2007).

The total accumulation of the most nutrients (Table 3) was kept constant most likely because the total DM was not altered. However, the linear increase in the accumulation of $\mathrm{Ca}$ (maximum of $1.12 \mathrm{~g} \mathrm{plant}^{-1}$ ) and $\mathrm{Mn}$ (maximum of 25.45 mg plant ${ }^{-1}$ ) was verified in the physic nut plants (Table 3 ). Although the Mg concentration was reduced in the leaf, its total accumulation in the plant $\left(1.4 \mathrm{~g} \mathrm{plant}^{-1}\right)$ did not change (Tables 2 and 3).

Commonly, high concentrations of $\mathrm{K}$ in the soil solution cause an imbalance in the Mg uptake. This occurs because the availability of nutrients is related not only to the concentration of cations in the soil but also to the ionic interactions between them (such as antagonistic interactions between $\mathrm{K}, \mathrm{Ca}$ and $\mathrm{Mg}$ ), which can occur both in the soil and in the plant and influence the availability and uptake of the elements (Tisdale et al., 1985). However, even with increased accumulation of $\mathrm{Ca}$ and $\mathrm{K}$ in the plants, the accumulation of $\mathrm{Mg}$ was not affected, most likely

Table 3. Regression equations referring to the accumulation of $\mathrm{N}, \mathrm{P}, \mathrm{K}, \mathrm{Ca}, \mathrm{Mg}, \mathrm{S}\left(\mathrm{g} \mathrm{plant}^{-1}\right.$ ) and $\mathrm{B}$, $\mathrm{Cu}, \mathrm{Fe}, \mathrm{Mn}$ and $\mathrm{Zn}\left(\mathrm{mg} \mathrm{plant}^{-1}\right)$ in physic nut plants as affected by $\mathrm{K}$ rates, 150 days after transplant

\begin{tabular}{clc}
\hline Nutrient & \multicolumn{1}{c}{ Equation } & $\mathbf{R}^{2}$ and significance \\
$N$ & $\mathrm{y}=2.09$ & $\mathrm{~ns}$ \\
$\mathrm{P}$ & $\mathrm{y}=0.22$ & $\mathrm{nS}$ \\
$\mathrm{K}$ & $\mathrm{y}=0.81+0.0183 \mathrm{x}$ & $0.85^{\star *}$ \\
$\mathrm{Ca}$ & $\mathrm{y}=0.83+0.0018 \mathrm{x}$ & $0.23^{\star *}$ \\
$\mathrm{Mg}$ & $\mathrm{y}=1.40$ & $\mathrm{~ns}$ \\
$\mathrm{~S}$ & $\mathrm{y}=0.20$ & $\mathrm{nS}$ \\
$\mathrm{B}$ & $\mathrm{y}=4.79$ & $\mathrm{nS}$ \\
$\mathrm{Cu}$ & $\mathrm{y}=0.62$ & $\mathrm{~ns}$ \\
$\mathrm{Fe}$ & $\mathrm{y}=26.38$ & $\mathrm{~ns}$ \\
$\mathrm{Mn}$ & $\mathrm{y}=11.48+0.0873 x$ & $0.73^{\star *}$ \\
$\mathrm{Zn}$ & $\mathrm{y}=2.38$ & $\mathrm{~ns}$ \\
\hline
\end{tabular}

** significant at 0.01 ; ns - not significant by $\mathrm{F}$ test because Mg provided by the dolomitic limestone was sufficient to avoid imbalances in the uptake of this nutrient.

As a function of the increase of $\mathrm{K}$ fertilization, there was a linear increase in the total accumulation of $\mathrm{K}$ in the physic nut seedlings (Table 3), which reinforces the hypothesis that the plants absorbed a quantity of $\mathrm{K}$ greater than their need.

At the end of the experiment, larger rates of $K$ used in fertilization increased the content of exchangeable $\mathrm{K}$ in the soil in a concentration-dependent manner (Figure 1A). The $\mathrm{K}$ rate of $160 \mathrm{mg} \mathrm{dm}^{-3}$ of soil elevated the content of exchangeable $\mathrm{K}$ in the soil from 7.8 (initial) to $80.3 \mathrm{mg} \mathrm{dm}^{-3}$. From the calculated rate of $86 \mathrm{mg} \mathrm{dm}^{-3}$, K fertilization not only increased the content of exchangeable $\mathrm{K}$ in the soil but also increased the non-exchangeable $\mathrm{K}$ (Figure 1B), which is due to the fact that different forms of $\mathrm{K}$ are in equilibrium in the soil (Rosolem et al., 2006). The rates of 80,120 and $160 \mathrm{mg} \mathrm{dm}^{-3}$ contributed, respectively, with $0.22,0.26$ and $0.63 \mathrm{~g}$ of $\mathrm{K}$ to the stock of nonexchangeable and/or fixed $\mathrm{K}$ in the soil (Table 4).

When the rates of 0 and $40 \mathrm{mg} \mathrm{dm}^{-3}$ were used the nonexchangeable fraction of $\mathrm{K}$ supplied the $\mathrm{K}$ demand of the plants

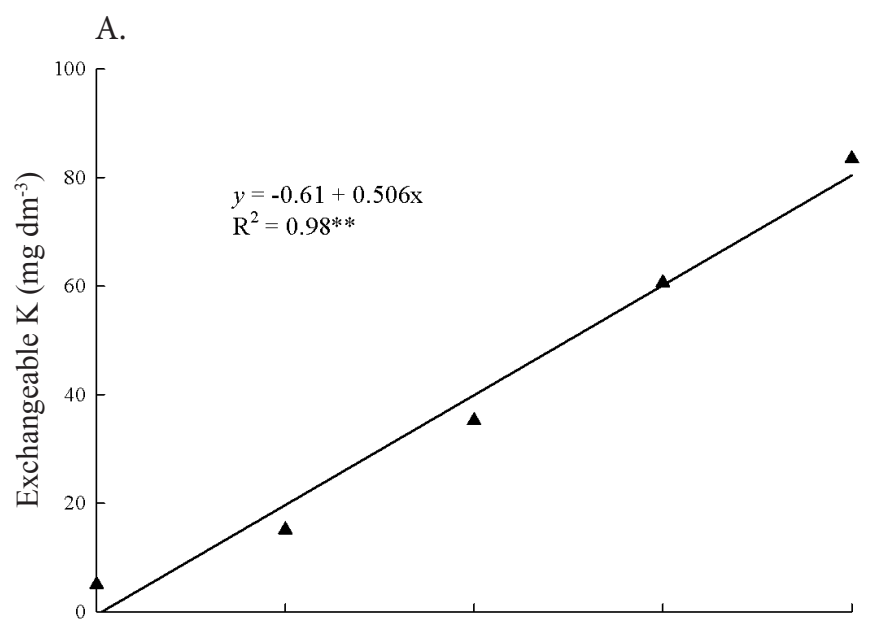

B.

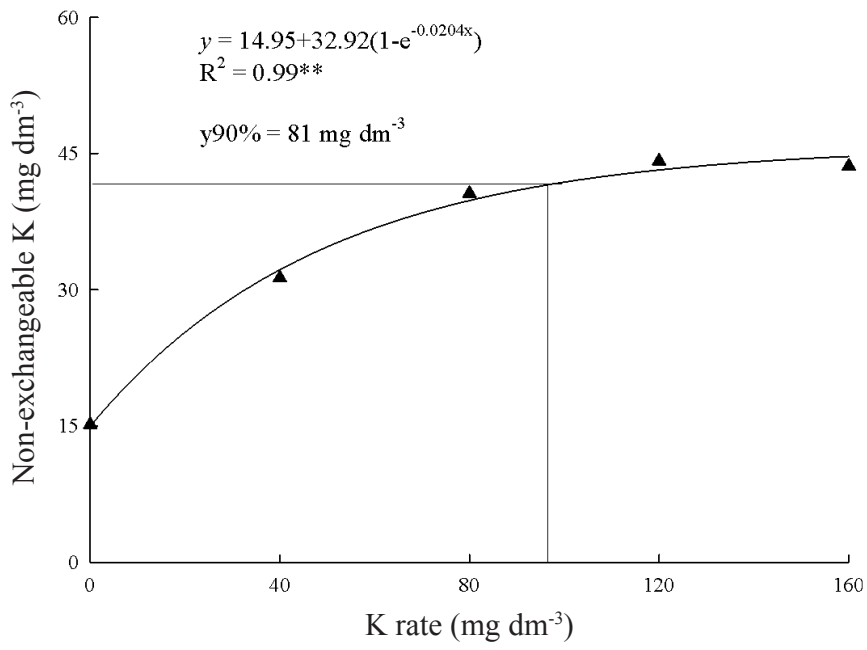

** significant at 0.01

Initial level of exchangeable K: $7.8 \mathrm{mg} \mathrm{dm}^{-3}$; Initial level of non-exchangeable $\mathrm{K}: 42.2 \mathrm{mg} \mathrm{dm}^{-3}$

Figure 1. Levels of exchangeable $K(A)$ and nonexchangeable $\mathrm{K}(\mathrm{B})$ in soil after 150 days of phisic nut cultivation as affected by $\mathrm{K}$ rates 
Table 4. Potassium balance in soil-plant system after 150 days of physic nut cultivation as affected by potassium rates

\begin{tabular}{ccccc}
\hline $\begin{array}{c}\text { K rate } \\
\text { mg dm d }\end{array}$ & $\begin{array}{c}\mathbf{K} \\
\text { fertilization }^{\mathbf{3}}\end{array}$ & $\begin{array}{l}\text { K uptake } \\
\text { by plant }^{2}\end{array}$ & $\begin{array}{c}\Delta \mathbf{K} \\
\text { soil }^{\mathbf{3}}\end{array}$ & $\begin{array}{c}\mathbf{K} \\
\text { balance }^{\mathbf{4}^{*}}\end{array}$ \\
\cline { 2 - 5 } 0 & 0 & $0.63 \mathrm{~d}$ & $-0.14 \mathrm{e}$ & $-0.49 \mathrm{c}$ \\
40 & 2 & $1.67 \mathrm{c}$ & $+0.37 \mathrm{~d}$ & $-0.04 \mathrm{~b}$ \\
80 & 4 & $2.41 \mathrm{~b}$ & $+1.37 \mathrm{c}$ & $+0.22 \mathrm{ab}$ \\
120 & 6 & $3.10 \mathrm{ab}$ & $+2.64 \mathrm{~b}$ & $+0.26 \mathrm{ab}$ \\
160 & 8 & $3.59 \mathrm{a}$ & $+3.79 \mathrm{a}$ & $+0.63 \mathrm{a}$ \\
\hline
\end{tabular}

Means followed by different letters in the columns are different according the confidence interval test $(p=0.05)$

1 Potassium supplied as $\mathrm{KCl}$

2 Potassium uptakes by entire plant (root + stem/petiole + leaves)

$\Delta \mathrm{K}$ soil $=\mathrm{K}$ available at the end of 150 days $-\mathrm{K}$ initially available $(0.39 \mathrm{~g})$

${ }^{4} \mathrm{~K}$ balance in soil-plant system $=$ (K fertilization $-\mathrm{K}$ uptake by plant) $-\Delta \mathrm{K}$ soil

* A negative value indicates that there was a release of non-exchangeable $K$, and a positive value indicates that there was fixation of $\mathrm{K}$ in the soil minerals

(Table 4). In the absence of $\mathrm{K}$ fertilization, the contribution of the non-exchangeable $\mathrm{K}$ fraction was $0.49 \mathrm{~g}$, which represented $78 \%$ of all $\mathrm{K}$ absorbed by the plant. Fertilization with $40 \mathrm{mg} \mathrm{dm}^{-3}$, even increasing the exchangeable $\mathrm{K}$ content, reduced the $\mathrm{K}$ stock in $0.04 \mathrm{~g}$ the non-exchangeable fraction. These results indicate that physic nut can absorb $\mathrm{K}$ from the non-exchangeable fraction of the soil, which alludes to practical applications and explains, in part, the observation that physic nut exhibits a low demand for $\mathrm{K}$ in the initial growth phase and a low response to $\mathrm{K}$ fertilization. Thus, the fact that the plant be able to absorb $\mathrm{K}$ from the nonexchangeable fraction can mask the fertilization effects.

When the exchangeable $\mathrm{K}$ in the soil is low, the $\mathrm{K}$ from the non-exchangeable fraction contributes to the total $\mathrm{K}$ uptaken by the plants (Silva et al., 1995). One of the main mechanisms that facilitates this process is the capacity of the plants to absorb $\mathrm{K}$ at low $\mathrm{K}$ soil contents (Wang et al., 2011), which occurs because the exhaustion of $\mathrm{K}$ at the root surface generates a concentration gradient that results in release of non-exchangeable K (Hinsinger et al., 1993). However, there are more specific factors that can release non-exchangeable $\mathrm{K}$, such as increases in the soil contents of $\mathrm{NH}_{4}^{+}$(Scherer, 1993), $\mathrm{Ca}^{2+}, \mathrm{Mg}^{2+}$ and $\mathrm{Na}^{2+}$ and, mainly, the exudation of organic acids by the roots (Wang et al., 2011). The primary mechanism that governs the release of non-exchangeable $\mathrm{K}$ by physic nut remains unknown and thus merits future studies to elucidate the potential for physic nut cultivation.

\section{Conchusions}

1. Higher rates of $\mathrm{K}$ used in fertilization allow greater uptake of $\mathrm{K}, \mathrm{Ca}$ and $\mathrm{Mn}$ by physic nut seedlings.

2. The total dry mass production of physic nut is not altered by increases in potassium fertilization.

3. The physic nut can release and absorb $\mathrm{K}$ from the nonexchangeable soil fraction.

\section{ACKNOWLedgments}

To FAPESP (State of São Paulo Research Foundation), for providing a scholarship to first author.

\section{Literature Cited}

Arruda, F. P.; Beltrão, N. E. de M.; Andrade, A. P.; Pereira, W. E.; Severino, L. S. Cultivo de pinhão-manso (Jatropha Curcas L.) como alternativa para o semi-árido nordestino. Revista Brasileira de Oleaginosas e Fibrosas, v.8, p.789-799, 2004.

Bhering, L. L.; Laviola, B. G.; Salgado, C. C.; Sanchez, C. F. B.; Rosado, T. B.; Alves, A. A. Genetic gains in physic nut using selection indexes. Pesquisa Agropecuária Brasileira, v.47, p.402-408, 2012.

Cantarella, H. Nitrogênio. In: Novais, R. F. Novais, R. F.; Alvarez V., V. H.; Barros, N. F.; Fontes, R. L. F.; Cantarutti, R. B.; Neves, J. C. L. Fertilidade do solo. Viçosa: SBCS, 2007. Cap. 7, p.375-470.

Carvalho, W. A.; Espindola, C. R.; Pacola, A. A. Levantamento de solos da Fazenda Lageado. Botucatu: FCA/UNESP, 1983. 95p. (Boletim Científico da Faculdade de Ciências Agronômicas UNESP).

Castilhos, D. D.; Meurer, E. J.; Kampf, N.; Pinto, L. F. S. Mineralogia e fontes de potássio em solos do Rio Grande do Sul cultivados com arroz irrigado. Revista Brasileira de Ciência do Solo, v.26, p.579-587, 2002.

Ernani, P. R.; Bayer, C.; Almeida, J. A. Mobilidade vertical de cátions influenciada pelo método de aplicação de cloreto de potássio em solos com carga variável. Revista Brasileira de Ciência do Solo, v.31, p.393-402, 2007.

Fonseca, J. A.; Meurer, E. J. Inibição da absorção de magnésio pelo potássio em plântulas de milho em solução nutritiva. Revista Brasileira de Ciência do Solo, v.21, p.47-50, 1997.

Hinsinger, P.; Elsass, F.; Jaillard, B. Root-induced irreversible transformation of a trioctahedral mica in the rhizosphere of rape. Soil Science, v.44, p.535-545, 1993.

Kaminski, J.; Brunetto, G.; Moterle, D. F.; Rheinheimer, D. S. Depleção de formas de potássio do solo afetada por cultivos sucessivos. Revista Brasileira de Ciência do Solo, v.31, p.1003-1010, 2007.

Knudsen, D.; Peterson, G. A.; Pratt, P. F. Lithium, sodium, and potassium. In: Page, A. L. Methods of soil analysis: Chemical and microbiological properties. Madison: American Society of Agronomy, 1986. Parte 2, p.225-246.

Laviola, B. G.; Dias, L. A. S. Teor e acúmulo de nutrientes em folhas e frutos de pinhão-manso. Revista Brasileira de Ciência do Solo, v.32, p.1969-1975, 2008.

Lima, R. L. S. Severino, L. S.; Cazzeta, J. O.; Azevedo, C. A. V.; Sofiatti, V.; Arriel, N. H. S. Posição da folha e estádio fenológico do ramo para análise foliar do pinhão-manso. Revista Brasileira de Engenharia Agrícola e Ambiental, v.15, p.1068-1072, 2011a.

Lima, R. L. S.; Severino, L. S.; Cazzeta, J. O.; Azevedo, C. A. V. de; Sofiatti, V.; Arriel, N. H. S. Redistribuição de nutrientes em folhas de pinhão-manso entre estádios fenológicos. Revista Brasileira de Engenharia Agrícola e Ambiental, v.15, p.1175-1179, 2011 b.

Malavolta, E.; Vitti, G. C.; Oliveira, S. A. Avaliação do estado nutricional das plantas: princípios e aplicações. 2.ed. Piracicaba: Associação Brasileira para Pesquisa da Potassa e Fosfato, 1997. 201p. 
Marschner, H. Mineral nutrition of higher plants. 2.ed. New York: Academic Press, 1995. 889p.

Meurer, E. J. Potássio. In: Fernandes, M. S. Nutrição mineral de plantas. Viçosa: SBCS, 2006. Cap.11, p.281-298.

Nithiyanantham, S.; Siddhuraju, P.; Francis, G. A promising approach to enhance the total phenolic content and antioxidant activity of raw and processed Jatropha curcas L. kernel meal extracts. Industrial Crops and Products, v.43, p.261- 269, 2013.

Oliveira, E. L.; Faria, M. A.; Evangelista, A. W. P.; Melo, P. C. Resposta do pinhão-manso à aplicação de níveis de irrigação e doses de adubação potássica. Revista Brasileira de Engenharia Agrícola e Ambiental, v.16, p.593-598, 2012.

Pavinato, P. S.; Calonego, J. C.; Camili, E. C.; Alavarez, A. C.; Leite, G. H.; Boaro, C. S. F. Influência da adubação potássica na produção e na atividade de enzimas pós-colheita em escarola (Cichorium endivia L.). Ambiência, v.5, p.505-520, 2009.

Payton, M. E.; Miller, A. E.; Raun, W. R. Testing statistical hypotheses using standard error bars and confidence intervals. Communications in Soil Science and Plant Analysis, v.31, p.547-551, 2000.

Prado, R. M.; Braghirolli, L. F.; Natale, W.; Corrêa, M. C. M.; Almeida, E. V. Aplicação de potássio no estado nutricional e na produção de matéria seca de mudas de maracujazeiro-amarelo. Revista Brasileira de Fruticultura, v.26, p.295-299, 2004.

Ramos Júnior, E. U.; Machado, R. A. F.; Olibone, D.; Castoldi, G.; Ramos, B. M. Crescimento de plantas de cobertura sob déficit hídrico. Semina, v.34, p.47-56, 2013.
Raij, B.; Andrade, J. C.; Cantarella, H. Quaggio, J. A. Análise química para avaliação da fertilidade de solos tropicais. Campinas: Instituto Agronômico, 2001. 285p.

Rengel, Z.; Damon, P. M. Crops and genotypes differ in efficiency of potassium uptake and use. Physiologia Plantarum, v.133, p.624-636, 2008.

Rosolem, C. A.; Santos, F. P.; Foloni, J. S. S.; Calonego, J. C. Potássio no solo em conseqüência da adubação sobre a palha de milheto e chuva simulada. Pesquisa Agropecuária Brasileira, v.41, p.1033-1040, 2006.

Scherer, H. W. Dynamics and availability of the nonexchangeable $\mathrm{NH}_{4}-\mathrm{N}$ : A review. European Journal of Agronomy, v.2, p.149-160, 1993.

Silva, D. N.; Meurer, E. J.; Kampf, N.; Borkert, C. M. Mineralogia e formas de potássio em dois Latossolos do Estado do Paraná e suas relações com a disponibilidade para as plantas. Revista Brasileira de Ciência do Solo, v.19, p.433-439, 1995.

Silva, E. B.; Tanure, L. P. P.; Santos, S. R.; Resende Júnior, P. S. Sintomas visuais de deficiências nutricionais em pinhãomanso. Pesquisa Agropecuária Brasileira, v.44, p.392-397, 2009.

Tisdale, S. L.; Nelson, W.; Beaton, J. D. Soil fertility and fertilizers. 4.ed. New York: Macmillan Publishing Company, 1985. 754p.

Wang, H. Y.; Shen, Q. H.; Zhou, J. M.; Wang, J.; Du, C. W.; Chen, X. Q. Plants use alternative strategies to utilize nonexchangeable potassium in minerals. Plant and Soil, v.343, p.209-220, 2011 